\title{
WILLIAM ANDERSON HUTCHESON
}

William ANDerson Hutcheson, a Fellow of the Institute since 1894, died at his home in Gladstone, New Jersey, on 19 November 1942 after a brief illness, at the age of 74 .

Mr Hutcheson was born in Greenock, Scotland. He was educated at the Greenock Academy and at Merchiston Castle School near Edinburgh.

On leaving school in $1887 \mathrm{Mr}$ Hutcheson entered the service of the Scottish Widows' Fund and Life Assurance Society.

After a transfer to the London office of the Scottish Widows' Mr Hutcheson became for a short time assistant to George King, then actuary of the London Assurance Corporation. In I 899 he was offered the position of Associate Actuary of the Mutual Life Insurance Company. of New York under Emory McClintock. He accepted this offer, beginning a period of over forty years' service with the Mutual Life. On Mr McClintock's retirement in 19 II he became Actuary of the Mutual and was later appointed Vice-President and Actuary, which position he held until his retirement in $194^{\circ}$.

Mr Hutcheson was very active in the affairs of the Actuarial Society of America of which he became a Fellow by examination in 1902 . He served on its Council continuously from 1907 until his death-a period of 35 years. He was Vice-President from 1914 to 1916 and from 1918 to 1920 , and President from 1920 to 1922.

In 1902 he contributed a paper to the fournal on 'American Valuation 'Tables' and he alse contributed several papers to the Transactions of the Actuarial Society. He was particularly interested in the historical aspects of life insurance and of the actuarial profession, and having a retentive memory was often able to furnish detailed information as to past events affecting the life insurance business or of interest to the actuary, both in Great Britain and in America.

Mr Hutcheson was also a Fellow of the Faculty of Actuaries, the American Institute of Actuaries and the Casualty Actuarial Society. For several years he was Chairman of the Committee of Actuaries of the Commission on Pensions of the City of New York and during the first world war was Chairman of an Advisory Committee of the Y.M.C.A. dealing with insurance plans for that organization's secretaries overseas.

Mr Hutcheson's death removes one of the leading figures in America of the actuarial world of the last generation. He was a man of complete integrity who, during the whole of a long and active life, deserved and enjoyed the respect of all who knew him. 